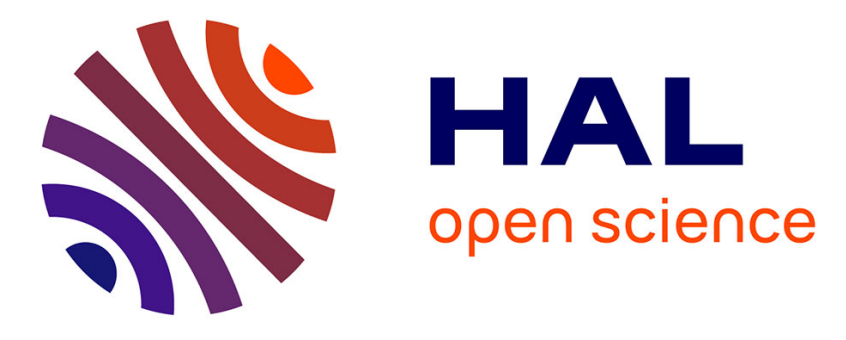

\title{
Seasonal and spatial variations of stream insect emergence in an intensive agricultural landscape
}

Julien Raitif, Manuel Plantegenest, Océane Agator, C. Piscart, Jean-Marc Roussel

\section{- To cite this version:}

Julien Raitif, Manuel Plantegenest, Océane Agator, C. Piscart, Jean-Marc Roussel. Seasonal and spatial variations of stream insect emergence in an intensive agricultural landscape. Science of the Total Environment, 2018, 644, pp.594 - 601. 10.1016/j.scitotenv.2018.07.021 . hal-01848468

HAL Id: hal-01848468

https://institut-agro-rennes-angers.hal.science/hal-01848468

Submitted on 11 Sep 2018

HAL is a multi-disciplinary open access archive for the deposit and dissemination of scientific research documents, whether they are published or not. The documents may come from teaching and research institutions in France or abroad, or from public or private research centers.
L'archive ouverte pluridisciplinaire $\mathbf{H A L}$, est destinée au dépôt et à la diffusion de documents scientifiques de niveau recherche, publiés ou non, émanant des établissements d'enseignement et de recherche français ou étrangers, des laboratoires publics ou privés. 


\section{AGROECOSYSTEMS}

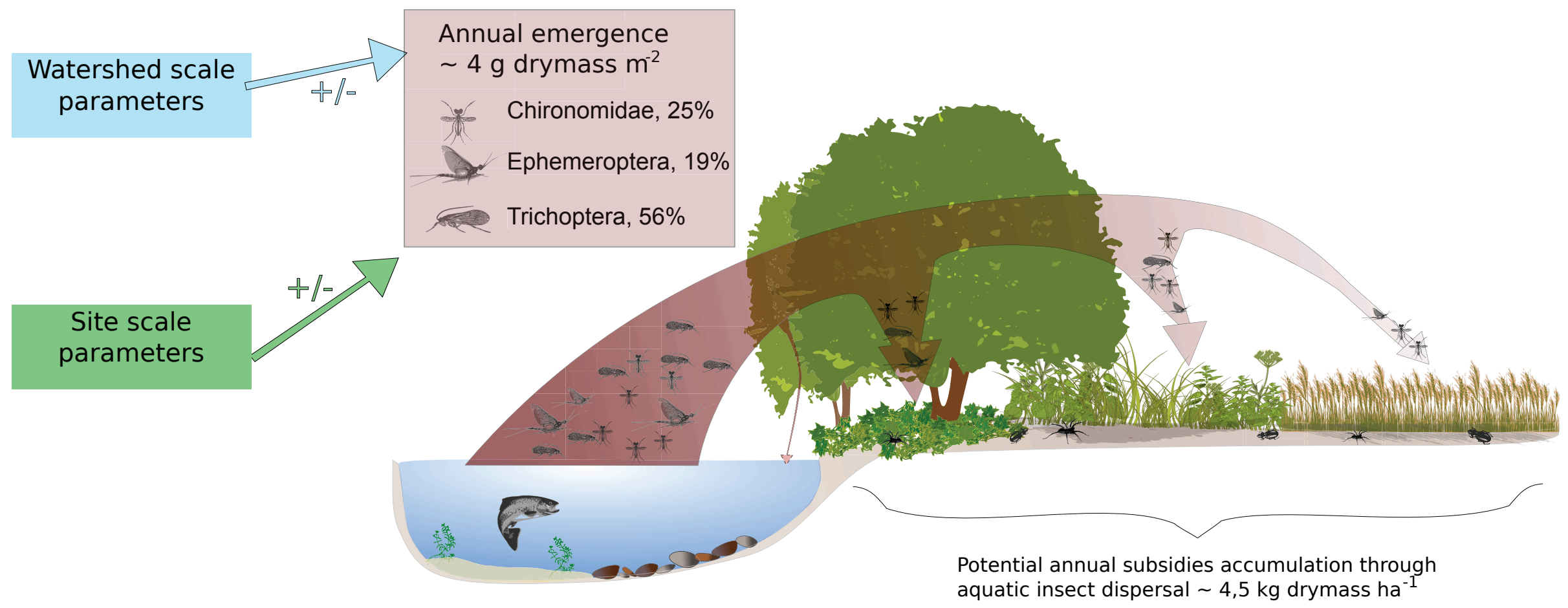


Highlights

- Aquatic insects emergence reaches $4 \mathrm{~g}$ drymass (DM). $\mathrm{m}^{-2} \cdot \mathrm{y}^{-1}$ in agricultural streams

- Trichoptera contributed the most, followed by Chironomidae then Ephemeroptera

- Emergence happened throughout the year with taxon-specific patterns

- Several parameters linked to agriculture influenced emerging DM of aquatic insects

- We estimated potential deposit of aquatic subsidies on land at $4.5 \mathrm{~kg}$ DM.ha ${ }^{-1} \cdot \mathrm{y}^{-1}$ 
Seasonal and spatial variations of stream insect emergence in an intensive agricultural landscape

Julien Raitif ${ }^{1,2}$, Manuel Plantegenest ${ }^{1}$, Océane Agator $^{2}$, C. Piscart ${ }^{3}$, Jean-Marc Roussel ${ }^{2,4}$

${ }^{1}$ IGEPP, Institut de Génétique, Environnement et Protection des Plantes, Agrocampus Ouest, 65 rue de Saint Brieuc, F-35042 Rennes, France

${ }^{2}$ INRA, Agrocampus-Ouest, Ecology and Ecosystem Health, 65 rue de Saint-Brieuc, F-35042 Rennes, France

${ }^{3}$ Université de Rennes 1 - UMR CNRS ECOBIO 6553 - Campus Beaulieu, 263 Av. du Général Leclerc, F-35042 Rennes Cedex, France

${ }^{4}$ Management of aquatic ecosystems in agricultural watersheds, INRA, Agence Française pour la Biodiversité, Rennes, France 
2 A growing amount of literature exists on reciprocal fluxes of matter and energy between 3 ecosystems. Aquatic subsidies of winged aquatic insects can affect terrestrial ecosystems 4 significantly, but this issue is rarely addressed in agroecosystems. By altering the production 5 of benthic macroinvertebrates, agricultural practices could increase or decrease the strength of 6 aquatic subsidies and subsequently the provision of several ecosystem services to agriculture. 7 Effects of seasons and environmental variables on aquatic insect emergence were investigated 8 in third-order agricultural streams in northwestern France. Most emerging dry mass (DM) of 9 caught insects belonged to Trichoptera (56\%), Chironomidae (25\%) and Ephemeroptera 10 (19\%). We estimated that annual emerging dry mass of aquatic insects ranged between 1,445 11 and $7,374 \mathrm{mg} / \mathrm{m}^{2} / \mathrm{y}$ depending on the stream. Seasonal variations were taxon-specific, with 12 Ephemeroptera emerging only in spring, Trichoptera emerging in spring and early summer, and Chironomidae emerging throughout the year. The percentage of watershed area covered by agriculture, ammonium concentration and hypoxia positively influenced emerging DM of Chironomidae but negatively influenced Ephemeroptera. Emerging DM of Trichoptera and 16 Ephemeroptera increased significantly as water conductivity and temperature increased. 17 Channel openness increased the emerging DM of all taxonomic groups, but Chironomidae were more abundant in narrow, incised streams. Assuming that the biomass of aquatic invertebrates ultimately disperse toward terrestrial habitats, nutrient accumulations on land near streams were estimated to reach $0.5-2.3 \mathrm{~kg} \mathrm{C} \mathrm{ha}^{-1} \mathrm{y}^{-1}, 0.1-0.5 \mathrm{~kg} \mathrm{~N} \mathrm{ha}^{-1} \mathrm{y}^{-1}$ and $0.005-$

$210.03 \mathrm{~kg} \mathrm{P} \mathrm{ha}^{-1} \mathrm{y}^{-1}$, depending on the stream. This suggests a significant flux of aquatic nutrients to agroecosystems and the need for future studies of its potential influence on the ecosystem services provided to agriculture. 
25 Keywords: agroecosystems; winged stream insects; emergence; aquatic subsidies;

26 environmental factors; seasonal variations 
Riverine ecosystems host a rich but endangered biodiversity (Naiman and and Décamps 1997;

Dudgeon et al. 2006) that could play a significant role in providing ecosystem services. In a recent review, Hanna et al. (2017) listed more than 30 types of services that riverine ecosystems provide, and observed a potential distinction between the location and the spatial extent at which these services are produced and delivered. Growing evidence indicates that ecosystems that were previously considered unrelated can interact. Several studies have demonstrated the existence of reciprocal exchanges of matter and energy between aquatic and terrestrial habitats (e.g. Polis et al. 1997, Richardson et al. 2010, Bartels et al. 2012). These "aquatic subsidies" can significantly influence the functioning of terrestrial ecosystems (Jackson and Fisher 1986; Havik et al. 2014; Dreyer et al. 2015), but this is poorly documented for agricultural landscapes. Aquatic subsidies can also influence several ecosystem services supplied to agriculture (Raitif et al., in revision), and future studies are required to estimate the magnitude of their influence.

Adult aquatic winged insects are effective vectors of aquatic subsidies (Bartels et al. 2012) since they are abundant in almost all freshwater ecosystems, and their ability to disperse is substantial (Muehlbauer et al. 2014). Several studies have demonstrated their role as prey for terrestrial predators (e.g. birds, Gray 1993; carabids, Hering and Plachter 1997; spiders, Paetzold et al. 2005), providing a valuable source of nutrients for entire terrestrial ecosystems (Dreyer et al. 2015). Agricultural practices can regulate the production of benthic al. 2010; Johnson et al. 2013a; Beketov et al. 2013); changing the flow regime and aquatic habitats (Rabení et al. 2005; Kennedy and Turner 2011; Wagenhoff et al. 2011; Magbanua et al. 2016); and modifying riparian vegetation (Deegan and Ganf 2008) and water temperature 
52 (Nagasaka and Nakamura 1999; Sponseller et al. 2001). Consequently, the influence of

53 agriculture in watersheds on the emergence of stream winged insects could increase or 54 decrease the strength of aquatic subsidies provided to terrestrial ecosystems. For instance, stream insect communities are usually dominated by small taxa with greater ability to disperse by flight in agricultural landscapes (Stenroth et al. 2015; Carlson et al. 2016; Greenwood and Booker 2016). While insect emergence depends on season and weather conditions (Corbet 1964), few studies quantify these influences or analyze their variability in agricultural landscapes. For instance, Shieh et al. (2003) and Gücker et al. (2011) published seasonal variations of aquatic insect production in two agricultural streams, but not emergence data. However, information on spatial and temporal variation in the emerging biomass of aquatic insect taxa is essential to accurately estimate the amount of aquatic subsidies annually produced by agricultural streams.

In this study, we quantified the spatial and seasonal emergence of aquatic insects in 12 sites located in intensive agricultural landscapes. We aimed to (i) assess temporal variation in dry mass (DM) for the main emerging aquatic insect taxa and (ii) highlight the influence of environmental parameters at different spatial scales on emergence patterns. We hypothesized that agriculture intensification would drive emergence of aquatic insects at both local and watershed scales, and notably enhance Chironomidae (Diptera) that could emerge throughout the year.

\section{Methods}

\subsection{Study sites}

The study was performed in the Ille-et-Vilaine county (Brittany), western France. This area sits on sedimentary rocks (schist and sandstone) with occasional layers of aeolian loam deposits. The climate is oceanic, with a mean annual temperature of $10.5-12.5^{\circ} \mathrm{C}$ and 
cumulative annual rainfall of approximately $700 \mathrm{~mm}$ (peaking in fall and winter) (Météo France 2017). Mean annual discharge of third-order streams in this part of Brittany is $0.65 \mathrm{~m}^{3}$ $\mathrm{s}^{-1}$, ranging from $0.06 \mathrm{~m}^{3} \mathrm{~s}^{-1}$ in September (end of summer) to $2.23 \mathrm{~m}^{3} \mathrm{~s}^{-1}$ in March (end of winter).

Intensive agricultural practices that rely on large amounts of inputs (fertilizers and pesticides) and extreme modifications of the landscape have altered terrestrial and aquatic ecosystems for decades (Piscart et al. 2009). Stream banks, deeply incised into thick arable ground, are destabilized by clearcutting of riparian vegetation, which results in sloughing, bank erosion, siltation and homogenization of stream substratum. Twelve sites were selected from 8 watersheds: Champagne, Roncelinais, Jardière, Rocher, Tertre, Ourmais, Bray, Ormal, Moulin, Fèvre, Vallée and Sauvagère (Table S1). Selection criteria was based according to (1) third-order permanent streams (Strahler classification), and (2) approximately $6 \mathrm{~m}$ wide and flowing along small-grain cereal fields (winter wheat or barley). We chose third-order streams to avoid summer drying of lower-order streams and fall and winter floods in higher-order streams, which would have impeded aquatic insect sampling. A drought occurred in 2016, resulting in very low discharge in winter 2016/2017 $\left(1 \mathrm{~m}^{3} \mathrm{~s}^{-1}\right)$. Mandatory grass strips $(\sim 8 \mathrm{~m}$ wide) separated streams from fields. This highly enriched buffer zone was dominated by nitrophilous plants belonging to a variety of families (Poaceae, Urticaceae, Apiaceae, etc.). Riparian vegetation near the stream bank consisted of shrubs, small trees (Salix sp.), and occasional larger trees (Quercus sp., Alnus sp.).

\subsection{Aquatic insect sampling}

We estimated aquatic insect emergence by deploying two emergence traps at each site. The traps consisted of a floating pyramidal tent $\left(1 \mathrm{~m}^{2}\right.$ at its base) made of nylon mesh and anchored to shorelines with ropes. Because substratum and water velocity strongly affect aquatic insect communities (Tachet et al. 2010), one trap was set in a deep and silty habitat 
and the other in a shallow gravel-pebble habitat to reflect the natural habitat heterogeneity of

102 each site. Adult insects were collected in a plastic bottle placed at the top of the trap and filled

103 with a mix of water, concentrated detergent and propylene glycol (approx. 20\%) to preserve

104 insects. Upon collection, aquatic insects were stored in alcohol (70\%).

105 Six campaigns of sampling were performed in 2016 and 2017: 17 - 26 May; 6 - 15 June; 27

106 June - 6 July; 12 - 21 September; 28 November - 5 December; 27 February - 9 March. At

107 each site, emergence trap was collected after 7 consecutive days and nights. Ten days per

108 campaign were necessary to proceed the 12 sites because of travel time between sites. The

109 timeline was designed to match aquatic insect emergence in such streams, which occurs

110 mainly in spring (March to June), to a lesser extent in summer and early fall (July to October),

111 and almost stops during cold and high-discharge winter months (Corbet 1964). Sampling was

112 carried out in December 2017 to confirm that insects do not emerge in coldest times at the end

113 of fall or during winter, but only at one site, to avoid damaging the equipment in windy and

114 flooded conditions. A total of 111 samples, totaling 777 days of aquatic insect emergence,

115 were collected; 11 samples were lost due to strong winds, flash floods or vandalism.

\subsection{Emergence abundance, dry mass and secondary production}

117 A stereomicroscope was used (1) to identify adult aquatic insects to the order level for

118 Ephemeroptera, Plecoptera, and Trichoptera, and (2) to separate Chironomidae from other

119 Diptera, the most abundant taxon in our sampling. Other insects, mainly Diptera, were not

120 considered because their contribution to total DM was low and did not justify the time-

121 consuming work required for identification. For Chironomidae, sub-samples $(1 / 2,1 / 4$ or $1 / 8)$

122 were obtained with a Motoda splitter (Motoda, 1959) when abundance was too high. Insects

123 were then dried at $60{ }^{\circ} \mathrm{C}$ for at least $24 \mathrm{~h}$. After cooling in a desiccator for another $24 \mathrm{~h}$, each

124 sample of each taxon was weighed to the nearest $0.2 \mathrm{mg}$ (on a Mettler Toledo AG). Insect

125 abundance (ind $\left.\mathrm{m}^{-2} \mathrm{~d}^{-1}\right)$ and DM $\left(\mathrm{mg} \mathrm{DM} \mathrm{m} \mathrm{m}^{-2}\right)$ were recorded for each site separately and 
126 then averaged (all sites combined) on a daily basis. Mean daily values obtained for each

127 campaign were prolonged to adjacent days (both forward and backward) to fill temporal gaps

128 between campaigns. Daily values were then summed to calculate cumulative seasonal

129 emerging DM (mg DM m ${ }^{-2}$ season $\left.^{-1}\right)$ using solstice and equinox dates as reference. We

130 calculated cumulative annual emerging DM as the sum of all seasonal values $\left(\mathrm{mg} \mathrm{DM} \mathrm{m}^{-2} \mathrm{y}^{-}\right.$

$131^{1}$ ). Biomass of emerging insects was then transformed to estimate secondary production at

132 each site using the mean Emergence:Production (E:P) ratio of 0.183 calculated by Poepperl et

133 al. (2000) for a similar agricultural stream. This ratio is relatively constant across taxa and

134 stream ecosystems (Statzner and Resh 1993; Gratton and Zanden 2009).

\section{$135 \quad 2.4$ Water quality, land use and habitat assessment}

136 Water quality data were provided for each study stream by the Agence de l'Eau Loire-

137 Bretagne (2017). Information on water temperature $\left({ }^{\circ} \mathrm{C}\right)$, turbidity (Formazin Nephelometric

138 Units, FNU), conductivity $\left(\mu \mathrm{S} \mathrm{cm}{ }^{-1}\right)$, nitrate $\left(\mathrm{mg} \mathrm{NO}_{3}^{-} \mathrm{L}^{-1}\right)$, ammonium $\left(\mathrm{mg} \mathrm{NH}_{4}^{+} \mathrm{L}^{-1}\right)$,

139 phosphorus (P) (mg total $\left.\mathrm{P} \mathrm{L}^{-1}\right)$, suspended matter (mg DM L $\left.{ }^{-1}\right)$ and oxygen saturation (\%)

140 were collected to reflect water quality at the watershed scale. Monthly values observed from

141 February 2016 to March 2017 were averaged to account for seasonal variations (Table S1).

142 Similarly, mean annual discharge was estimated for each stream using QGIS (QGIS

143 Development Team 2009), based on information available from the Réseau Hydrographique

144 Théorique (Pella et al. 2012). Watershed-scale variables also included watershed area and

145 land use (\% of agricultural, artificial and natural area), which were estimated using QGIS and

146 Corine Land Cover (CLC 2012). For each study site, local habitat features were measured or

147 visually assessed at mid-channel every $5 \mathrm{~m}$ along a 20-m reach on both sides of each trap:

148 surface water velocity $\left(\mathrm{cm} \mathrm{s}^{-1}\right)$, water depth $(\mathrm{cm})$, depth of soft sediments on the bottom $(\mathrm{cm})$,

149 stream width $(\mathrm{cm})$, bank height $(\mathrm{cm})$, channel openness $(\%)$ and substrate size (Table S1).

150 Substrate size was visually estimated following a modified Wentworth classification 
151 (Cummins 1962). A substrate score was calculated by multiplying mean particulate size of

152 each class by its observed proportion. Substrate heterogeneity was assessed by calculating the

153 Shannon index of the proportions of each substrate size class. The embankment score (stream

154 width divided by bank height) was used to estimate stream incision and erosion risk.

\section{$155 \quad 2.5$ Statistical analyses}

156 To study the temporal pattern of emergence, we fitted a linear mixed model (LMM) with a

157 Gaussian distribution, considering the sampling campaign as a fixed effect. The campaign

158 from 28 Nov to 5 Dec 2016 was ignored since data were available for only one site. To study

159 effects of environmental variables on emerging insect DM, another LMM with a Gaussian

160 distribution was applied. The small sample size precluded including both site- and watershed-

161 scale variables in a single model. Consequently, two separate models were fitted to the dataset

162 to assess effects of each set of variables.

163 The corvif() function of $\mathrm{R}$ software ( $\mathrm{R}$ Core Team 2013) was used to verify correlations

164 between variables before model computation (Zuur et al. 2009). Variables were removed 165 when $\mathrm{r}$ coefficient of correlation exceeded 0.8 and the variance inflation factor exceeded 4.5.

166 Accordingly, the following variables were selected and considered as fixed effects at the

167 watershed scale: water temperature, turbidity, conductivity, oxygen saturation, ammonium

168 nitrate concentrations and the percentage of watershed area covered by agriculture (cropland,

169 pastures). At the site scale, the variables selected were water depth, stream width, substratum

170 score, embankment score and channel openness. Prior to modeling, DM was log-transformed

$171(\log x+1)$ to better meet assumptions of normality. Since quantitative explanatory variables

172 were at different scales, we standardized them (mean=0, $\sigma=0.5$ ) using the standardize()

173 function of the R package arm (Gelman A. and Hill J. 2007). Samplings were nested in

174 site/watershed and campaign; these effects were thus included in the random part of temporal 
175 and spatial models respectively. When a random effect was non-significant (i.e. when

176 deviance explained was null), the model was re-run excluding it.

177 To identify variables that significantly influenced insect emergence, model averaging was

178 preferred to a best model strategy. Indeed, best model strategy select only one model with one

179 or several parameters and thus potentially exclude other model with different parameters

180 having a similarly good fit (Whittingham et al. 2006). In an explanatory approach, model

181 averaging is more appropriate as it produces estimates of parameters derived from multiple

182 weighted models. The model-averaging method (Burnham and Anderson 2003) was applied

183 at each spatial scale separately. Full models without interactions were used as starting models

184 for the dredge function of the R package MuMIn (Barton K. 2016). We retained all models

185 whose Akaike Information Criterion (AIC) corrected for small sample size (AICc; Grueber et

186 al. 2011) differed by less than 4 from the best model. We also checked for correlation

187 between fixed effects during the dredge process, but found no high correlation $($ all $r<0.7)$.

188 We performed model averaging on the selected subset using the model.avg function of the $\mathrm{R}$

189 package MuMIn. We considered explanatory variables significant when their associated 90\%

190 parameter confidence interval (CI) excluded zero (Arnold 2010). We assessed the significance

191 of their effect on variations in DM of each taxon by considering their effect intensity through

192 parameter estimates (i.e. effect size). Finally, the goodness-of-fit of all best averaged models

$193\left(\mathrm{R}^{2}\right)$ was assessed using the procedure developed by Nakagawa and Schielzeth (2013) for

194 mixed models using only significant explanatory variables. $\mathrm{R}^{2}$ marginal approximates the

195 variance explained by the fixed part of the model and $\mathrm{R}^{2}$ conditional the variance explained by the

196 complete model (fixed and random parts). All models were fitted using the R package lme4

197 (Bates et al. 2015). The same datasets were used for temporal and environmental modeling.

198 This allowed us to compare the AICc and $\mathrm{R}^{2}$ of models for each taxon. 


\subsection{Variations in environmental characteristics}

201 Stream discharge in 2016 peaked after heavy rainfall in March, two months before the first 202 sampling campaign at all sites. Discharge rapidly decreased in April and May $\left(<0.5 \mathrm{~m}^{3} \mathrm{~s}^{-1}\right.$ for 203 all streams), followed by a slight increase in June. No further rainfall increased stream 204 discharge until February 2017, resulting in a low regime $\left(<0.1 \mathrm{~m}^{3} \mathrm{~s}^{-1}\right)$ for all streams from 205 late summer to early winter. After some rainfall events in fall and winter, turbidity and 206 suspended matter concentrations increased sharply to a mean of $16 \mathrm{FNU}$ and $15 \mathrm{mg} \mathrm{DM} \mathrm{L}{ }^{-1}$, respectively. Mean water temperature $\left( \pm 1\right.$ standard deviation) ranged from $17.4{ }^{\circ} \mathrm{C}\left( \pm 2.0^{\circ} \mathrm{C}\right)$ in early summer to $4.1{ }^{\circ} \mathrm{C}\left( \pm 1.5^{\circ} \mathrm{C}\right)$ in winter. Mean water conductivity was highest in fall $\left(1,103 \mu \mathrm{S} \mathrm{cm} \mathrm{cm}^{-1} \pm 1,043\right)$ and peaked at $3,370 \mu \mathrm{S} \mathrm{cm}^{-1}$ in Garun. Oxygen saturation ranged

210 from $75 \%$ in summer to $100 \%$ in spring, with distinct annual variations among sites (Table

$211 \mathrm{~S} 1)$. Mean nitrate concentration was high throughout the year (20.4 $\left.\mathrm{mg} \mathrm{NO}_{3}^{-} \mathrm{L}^{-1} \pm 6.6\right)$, with 212 minimum values recorded at Illet and Veuvre and maximum values at Yaigne. Similarly, 213 ammonium and total $\mathrm{P}$ concentrations varied greatly among streams. Agriculture dominates 214 the landscape, covering a mean of $85 \%$ of the total watershed area, but variations in local 215 habitat characteristics were observed among sites. For instance, the channel was narrow with 216 dense riparian vegetation at Ormal but wider and almost completely open (no tree or shrub) at 217 Roncelinais. At Tertre, the stream flowed very slowly $\left(<0.1 \mathrm{~m} \mathrm{~s}^{-1}\right)$, with an accumulation of 218 fine sediment on the bottom, whereas at Jardière and Bray, water velocity, depth and 219 substratum were more heterogeneous. Mean annual values of site- and watershed-scale 220 variables are listed in Table S1. 


\subsection{Characteristics of aquatic insect emergence}

222 We caught 64,027 insects in emergence traps during the study, equaling $13.1 \mathrm{~g}$ of total DM

223 (all taxa combined). Chironomidae dominated total abundance (91\%) and contributed 25\% of 224 total caught DM. Trichoptera contributed the most to total DM (56\%) for only $6 \%$ of total 225 abundance. Ephemeroptera represented 19\% of total DM and 3\% of total abundance. 226 Plecoptera were rarely captured (only 23 individuals, $33.4 \mathrm{mg} \mathrm{DM}$ ) and thus were not 227 considered for further analysis. Total emerging DM caught in all sampling campaigns differed 228 among sites and ranged from 435 (at Jardière) to 2,091 mg DM (at Vallée) (Table S2).

\subsection{Temporal dynamics of insect emergence}

230 Daily emergence varied by taxon among sampling campaigns (Fig. 1a). That of Trichoptera 231 increased in spring and early summer (up to $19.35 \mathrm{mg} \mathrm{DM} \mathrm{m}^{-2} \mathrm{~d}^{-1}$ ), then decreased sharply 232 and remained low until the end of the study $\left(\mathrm{R}^{2}\right.$ marginal $\left.=34 \%\right)$. Daily emergence of 233 Trichoptera varied greatly among sites in July, ranging from 2.62 to $79.53 \mathrm{mg} \mathrm{DM} \mathrm{m}^{-2} \mathrm{~d}^{-1}$ at 234 Jardière and Fèvre, respectively (Table S3). Mean daily emergence of Chironomidae varied 235 less among sampling campaigns $\left(\mathrm{R}^{2}\right.$ marginal $\left.=11 \%\right)$, ranging from $2.89-6.44 \mathrm{mg} \mathrm{DM} \mathrm{m}^{-2} \mathrm{~d}^{-1}$, 236 with two distinct emergence peaks in May and July. Ephemeroptera emergence decreased 237 continuously $\left(\mathrm{R}^{2}{ }_{\text {marginal }}=34 \%\right)$ from spring $\left(\max .8 .2 \mathrm{mg} \mathrm{DM} \mathrm{m} \mathrm{d}^{-1}\right)$ to winter. No 238 emergence was observed for Ephemeroptera and Trichoptera in December, and it was very 239 low for Chironomidae $\left(\sim 0.17 \mathrm{mg} \mathrm{DM} \mathrm{m}^{-2} \mathrm{~d}^{-1}\right)$. Cumulative DM varied by taxon and season 240 (Fig. 1b). Over the entire study, that of Trichoptera was highest $\left(2,050 \mathrm{mg} \mathrm{DM} \mathrm{m}{ }^{-2}\right)$, followed 241 by those of Chironomidae $\left(1,120 \mathrm{mg} \mathrm{DM} \mathrm{m}^{-2}\right)$ and Ephemeroptera $\left(670 \mathrm{mg} \mathrm{DM} \mathrm{m}^{-2}\right)$. For all 242 taxa combined, cumulative DM reached 3,840 $\mathrm{mg} \mathrm{DM} \mathrm{m}^{-2} \mathrm{y}^{-1}$, ranging from 1,445 to 7,374 $243 \mathrm{mg} \mathrm{DM} \mathrm{m} \mathrm{y}^{-2}$ at Jardière and Fèvre, respectively. Using the Poepperl E:P ratio (2000), mean 244 secondary production was estimated at $21 \mathrm{~g} \mathrm{DM} \mathrm{m}^{-2} \mathrm{y}^{-1}$, ranging from 7.9 to $40 \mathrm{~g} \mathrm{DM} \mathrm{m}^{-2} \mathrm{y}^{-1}$ 245 at Jardière and Roncelinais, respectively. 
247 The environmental variables in the spatial models explained a significant percentage of the 248 variation in emerging insects DM, and noticeable differences were observed among taxa 249 (Table 1). For Chironomidae, the spatial models performed better $\left(\mathrm{R}^{2}\right.$ marginal $=15.9 \%$ and $25021.4 \%$ at the site and watershed scale, respectively) than the temporal model $\left(\mathrm{R}^{2}\right.$ marginal $=$ 251 10.9\%). Among spatial models, the model with watershed-scale variables fit the data better 252 but was less parsimonious than that with site-scale variables. Conversely, the temporal model 253 explained emerging Trichoptera and Ephemeroptera DM best $\left(\mathrm{R}^{2}{ }_{\text {marginal }} \sim 34 \%\right)$, the spatial 254 models $\mathrm{R}^{2}$ marginal ranging from 11.6 to $23.9 \%$, with watershed-scale variables explaining 255 Ephemeroptera better and site-scale variables explaining Trichoptera better.

256 Among the watershed-scale variables (Fig. 2a), the percentage of watershed area covered by 257 agriculture positively and significantly influenced emerging Chironomidae DM. Emerging 258 Chironomidae DM also increased significantly with increasing ammonium concentration and 259 decreasing dissolved oxygen concentration. Conversely, emerging Ephemeroptera DM was 260 significantly and negatively influenced by the percentage of watershed area covered by 261 agriculture and, although not significantly, negatively influenced by ammonium concentration 262 and positively influenced by dissolved oxygen concentration. Emerging Trichoptera and 263 Ephemeroptera DM increased significantly with increasing water conductivity and 264 temperature, but that of Trichoptera decreased with increasing turbidity. Among the site-scale 265 variables (Fig. 2b), channel openness positively and significantly influenced emerging DM of 266 all taxa. Emerging Trichoptera and Ephemeroptera DM increased significantly with 267 decreasing stream incision (higher embankment scores), while that of Chironomidae increased 268 significantly with decreasing stream width. Finally, emerging DM of Trichoptera increased significantly with increasing proportion of coarse substrate (i.e. higher substratum scores). 
271 We measured the biomass of aquatic insects emerging from third-order streams that drain

272 agricultural landscapes in western France. Mean total emerging DM of the three dominant 273 taxonomic groups living in temperate streams - Chironomidae, Ephemeroptera, and 274 Trichoptera - equaled approximately $4.0 \mathrm{~g} \mathrm{DM} \mathrm{m}^{-2} \mathrm{y}^{-1}$, ranging from 1.4-7.4 $\mathrm{g} \mathrm{DM} \mathrm{m}^{-2} \mathrm{y}^{-1}$ 275 depending on the stream. These results fall within the range of those reported in previous 276 studies for emerging aquatic insects in streams (listed in Table 2), although exceptionally 277 larger masses (> $\left.20 \mathrm{~g} \mathrm{DM} \mathrm{m}^{-2} \mathrm{y}^{-1}\right)$ have been observed in desert streams in Arizona, United 278 States (US) (Jackson and Fisher, 1986). In similar agricultural streams in Germany, Poepperl 279 (2000) reported lower annual biomass of emerging aquatic insects, especially for Trichoptera 280 and Ephemeroptera. The benthic biomass estimated by Gücker et al. (2011) was 281 approximately $20 \%$ that observed in this study. The high biomass estimates in our streams are 282 similar to those in other agriculture-dominated streams in several US states (Berg and 283 Hellenthal 1991; Shieh et al. 2003; Johnson et al. 2013b). Compared to other forest284 dominated streams, the biomass we estimated were four times greater for all taxa (combined) 285 than in a third order stream in China (Yuen and Dudgeon 2016), but five times smaller for 286 Chironomidae production than in a second order stream in Alabama (US) (Reynolds and 287 Benke 2012).

288 The influence of water temperature on benthic invertebrate production and emergence (Huryn 289 and Wallace 2000) was confirmed in our study by its positive correlation with Ephemeroptera 290 and Trichoptera emergence, but not that of Chironomidae. Since Chironomidae species 291 tolerate variations in water temperature better (Sponseller et al. 2001), the temperature range 292 observed in the study may not have been wide enough to influence their biomass. This study 293 confirmed that several agriculture-related variables can regulate the biomass of emerging 294 stream insects (Allan et al. 1997). Indeed, proportion of agricultural land in catchment is often 
associated with a decrease of emerging biomass of more sensitive taxa such as Ephemeroptera 296 and Trichoptera (Piscart et al. 2009, 2011) and the enhancement of tolerant taxa such as 297 Chironomidae (Lemly 1982). Sponseller et al. (2001) also reported that such pattern is 298 correlated with a higher algal biomass in agricultural catchments of second to third order 299 streams. At site scale in our study, the alteration of channel morphology by intensive 300 agriculture practices, approximated by stream width and embankment score, was detrimental 301 for Ephemeroptera and Trichoptera, while favoring Chironomidae biomass as reported in 302 previous studies (Quinn and Hickey 1990, Kennedy and Turner 2011). Accumulation of silt is commonly reported in such altered streams (Wagenhoff et al. 2011). Filter-feeding taxa (i.e.

304 Chironomidae and some Trichoptera) usually take advantage of fine sediment on the river 305 bed, while shredders and scrapers (i.e. most Ephemeroptera and some Trichoptera) are 306 hindered by these less favorable trophic conditions (Quinn and Hickey 1990, Compin and 307 Céréghino 2007). Conversely, we observed that biomass of emerging Ephemeroptera and 308 Trichoptera increased with increasing water conductivity. High conductivity is detrimental to 309 benthic macroinvertebrate biomass and diversity (Johnson et al. 2013b), but high nutrient 310 loads promote biofilm growth on stream substrate. Since biofilm is a major food source for 311 Ephemeroptera and some Trichoptera, their biomass may have increased at sites with both 312 high nutrient load and conductivity (Piscart et al. 2009). The positive correlation between 313 channel openness and emergence further corroborates this hypothesis. Incident light enhances 314 primary production in streams, favoring taxa that feed on algae and diatoms (Dance and 315 Hynes 1980) in each taxonomic groups (e.g. Baetis or Serratella mayflies, Glossomatid 316 caddisflies and many chironomids).

317 While Trichoptera emerged from early spring to summer, Ephemeroptera emerged only in 318 spring. When sorting samples in the lab, we observed at least 15 morphospecies of 319 Trichoptera (not taxonomically identified), suggesting that it had higher diversity than 
Ephemeroptera. Since each species has its own timing of emergence, the longer emergence 321 period for Trichoptera could have resulted simply from higher specific diversity.

322 Chironomidae were caught almost continuously except in the coldest period in December,

323 indicating that they emerged throughout the year, and were dominant taxa of emerging insects

324 in fall, winter and early spring. These temporal patterns suggest that stream insects can

325 subsidize surrounding agroecosystems for almost the entire year.

326 For accurate estimation of aquatic insect deposition on land, it is necessary to take into 327 account the flux of winged aquatic insects returning to streams. Notably, females of several 328 taxa lay their eggs at the surface or in water and died by drowning afterward (Baxter et al. 329 2017). Nonetheless, several studies estimated that terrestrial mortality of female aquatic 330 insects before oviposition is very high and exceeding 95\% on average (reviewed by Huryn 331 and Wallace 2000). This was reported for caddisfly, mortality of adult females reaching up to $33280 \%$ for Limnephilidae (Tricoptera, Enders and Wagner 1996) and 98.8\% for Baetidae 333 (Ephemeroptera, Werneke and Zick 1992), two families commonly found in agricultural 334 streams (Friberg et al. 2009). These observations confirm other investigations on the low 335 percentage of aquatic insects that could ultimately return to the stream $(1-3 \%$, Jackson and 336 Fisher 1986, Gray 1989).

337 Based on the range of invertebrate production in our study, a stream section $100 \mathrm{~m}$ long $\times 6 \mathrm{~m}$ 338 wide could produce 0.9-4.5 $\mathrm{kg} \mathrm{DM} \mathrm{y}^{-1}$ of emerging insects. Assuming that most winged 339 aquatic insects disperse up to $50 \mathrm{~m}$ from the stream on each bank, aquatic insect deposition on 340 land could reach $0.9-4.5 \mathrm{~kg} \mathrm{DM} \mathrm{ha} \mathrm{h}^{-1} \mathrm{y}^{-1}$. Using conversion factors of Evans-White et al. 341 (2005), this could result in accumulation of $0.5-2.3,0.1-0.5$ and $0.005-0.03 \mathrm{~kg} \mathrm{ha}^{-1} \mathrm{y}^{-1}$ of 342 carbon $(\mathrm{C})$, nitrogen $(\mathrm{N})$ and $\mathrm{P}$ on land, respectively, mainly in spring and summer. These 343 subsidies are similar to reciprocal fluxes reported for other ecosystems (see Landry and 344 Parrott 2016), notably the subsidies that carnivorous birds provide to freshwater or that deer 
345 provide from fields to forests. In addition, terrestrial net secondary production can reach 1.9$3464.0 \mathrm{~kg} \mathrm{C} \mathrm{ha}^{-1} \mathrm{y}^{-1}$ in temperate grasslands (Gratton and Zanden 2009), i.e. approximately twice 347 that expected along a stream $6 \mathrm{~m}$ wide. No estimate of secondary production exists for 348 temperate cropland, but some studies highlighted that terrestrial insect communities are less 349 diverse and abundant in agricultural areas (Benton et al. 2002; Batáry et al. 2012).

350 Taken together, these aspects suggest that aquatic subsidies provided by winged aquatic 351 insects could play a significant role in agroecosystem functioning near streams. Chironomidae 352 emerge throughout the year and can easily disperse over land (Muehlbauer et al. 2014), 353 potentially providing a valuable source of nutrients $(\mathrm{C}, \mathrm{N}, \mathrm{P})$ to receiving agroecosystems at 354 critical times of the year. Recent studies highlighted the importance of aquatic insects in 355 providing essential fatty acids to terrestrial consumers (Martin-Creuzburg et al. 2017; Popova et al. 2017). Many terrestrial predators (e.g. birds, Nakano and Murakami, 2001; spiders and carabids, Stenroth et al., 2015) likely feed on aquatic prey and could later shift to terrestrial 358 prey, including crop pests, as previously observed between fields and uncultivated areas 359 (Rand et al. 2006).

Multiple influences on aquatic insect emergence were identified at the local and watershed

362 scales, and some were directly related to agricultural practices. Our results suggest that emergence and dispersal of aquatic insects could substantially influence terrestrial ecosystem

364 functioning in landscapes with a dense waterway network. More studies are required on the 365 dispersal of aquatic winged insects and their deposition in terrestrial ecosystems to better 366 understand and quantify the ecological processes involved. This will help to assess effects of 367 the aquatic subsidies that streams provide on ecosystem services supplied to agriculture, such 368 as fertilization, biological control and pollination. 
370 This work received financial support from the Metaprogramm EcoServ of the French National

371 Institute for Agronomical Research (INRA) to JM Roussel, and from the French Ministry for

372 Reseach (PhD grant 2015-2018) to J Raitif. We thank two anonymous reviewers for their

373 constructive comments on the first version of the manuscript. 
375

376

377

378

379

380

381

382

383

384

385

386

387

388

389

390

391

392

393

394

395

396

397

398

399

400

401

402

403

404

405

406

407

408

409

410

Agence de l'eau Loire-Bretagne (2017) Base de données de bassin : OSUR. http://osur.eauloire-bretagne.fr/exportosur/Accueil. Accessed 1 Oct 2017

Allan D, Erickson D, Fay J (1997) The influence of catchment land use on stream integrity across multiple spatial scales. Freshw Biol 37:149-161. doi: 10.1046/j.13652427.1997.d01-546.x

Arnold TW (2010) Uninformative Parameters and Model Selection Using Akaike's Information Criterion. J Wildl Manag 74:1175-1178. doi: 10.1111/j.19372817.2010.tb01236.x

Bartels P, Cucherousset J, Steger K, et al (2012) Reciprocal subsidies between freshwater and terrestrial ecosystems structure consumer resource dynamics. Ecology 93:1173-1182

Barton K. (2016) MuMIn: multi-model inference. R package version 1.15.6. http://cran.rproject.org/web/packages/MuMIn/index.html

Batáry P, Holzschuh A, Orci KM, et al (2012) Responses of plant, insect and spider biodiversity to local and landscape scale management intensity in cereal crops and grasslands. Agric Ecosyst Environ 146:130-136. doi: 10.1016/j.agee.2011.10.018

Bates D, Maechler M., Boler B., Walker S. (2015) Fitting Linear Mixed-Effects Models Using lme4. Journal of Statistical Software 67:1-48. doi: 10.18637/jss.v067.i01

Baxter CV, Kennedy TA, Miller SW, et al (2017) Macroinvertebrate Drift, Adult Insect Emergence and Oviposition. In: Methods in Stream Ecology, Volume 1. Elsevier, pp $435-456$

Beketov MA, Kefford BJ, Schafer RB, Liess M (2013) Pesticides reduce regional biodiversity of stream invertebrates. Proc Natl Acad Sci 110:11039-11043. doi: 10.1073/pnas. 1305618110

Benton TG, Bryant DM, Cole L, Crick HQP (2002) Linking agricultural practice to insect and bird populations: a historical study over three decades: Farming, insect and bird populations. J Appl Ecol 39:673-687. doi: 10.1046/j.1365-2664.2002.00745.x

Berg MB, Hellenthal RA (1991) Secondary production of Chironomidae (Diptera) in a north temperate stream. Freshw Biol 25:497-505. doi: 10.1111/j.1365-2427.1991.tb01392.x

Burnham KP, Anderson DR (2003) Model Selection and Multimodel Inference: A Practical Information-Theoretic Approach. Springer Science \& Business Media

Carlson PE, McKie BG, Sandin L, Johnson RK (2016) Strong land-use effects on the dispersal patterns of adult stream insects: implications for transfers of aquatic subsidies to terrestrial consumers. Freshwater Biology 61:848-861. doi: $10.1111 /$ fwb. 12745

CLC (2012) Copernicus land monitoring services. http://land.copernicus.eu/paneuropean/corine-land-cover/clc-2012. Accessed 13 Jul 2016 
Compin A, Céréghino R (2007) Spatial patterns of macroinvertebrate functional feeding groups in streams in relation to physical variables and land-cover in Southwestern France. Landscape Ecology 22:1215-1225. doi: 10.1007/s0980-007-9101-y

Corbet PS (1964) Temporal Patterns of Emergence in Aquatic Insects. Can Entomol 96:264279. doi: 10.4039/Ent96264-1

Cross WF, Wallace JB, Rosemond AD, Eggert SL (2006) Whole-system nutrient enrichment increases secondary production in a detritus-based ecosystem. Ecology 87:1556-1565. doi: 10.1890/0012-9658(2006)87[1556:WNEISP]2.0.CO;2

Cummins KW (1962) An Evaluation of Some Techniques for the Collection and Analysis of Benthic Samples with Special Emphasis on Lotic Waters. Am Midl Nat 67:477-504. doi: $10.2307 / 2422722$

Dance KW, Hynes HBN (1980) Some effects of agricultural land use on stream insect communities. Environmental Pollution Series A, Ecological and Biological 22:19-28. doi: 10.1016/0143-1471(80)90078-1

Davis JM, Rosemond AD, Eggert SL, et al (2010) Nutrient enrichment differentially affects body sizes of primary consumers and predators in a detritus-based stream. Limnol Oceanogr 55:2305-2316. doi: 10.4319/lo.2010.55.6.2305

Deegan BM, Ganf GG (2008) The loss of aquatic and riparian plant communities: Implications for their consumers in a riverine food web. Austral Ecol 33:672-683. doi: 10.1111/j.1442-9993.2008.01834.x

Dreyer J, Townsend PA, Hook JC III, et al (2015) Quantifying aquatic insect deposition from lake to land. Ecology 96:499-509. doi: 10.1890/14-0704.1

Dudgeon D, Arthington AH, Gessner MO, et al (2006) Freshwater biodiversity: importance, threats, status and conservation challenges. Biol Rev 81:163-182. doi: $10.1017 / \mathrm{s} 464793105006950$

Enders G, Wagner R (1996) Mortality of Apatania fimbriata (Insecta: Trichoptera) during embryonic, larval and adult life stages. Freshwater Biology 36:93-104. doi: 10.1046/j.1365-2427.1996.00081.x

Evans-White MA, Stelzer RS, Lamberti GA (2005) Taxonomic and regional patterns in benthic macroinvertebrate elemental composition in streams. Freshw Biol 50:17861799. doi: $10.1111 / \mathrm{j} .1365-2427.2005 .01455 . x$

Friberg N, Skriver J, Larsen SE, et al (2009) Stream macroinvertebrate occurrence along gradients in organic pollution and eutrophication: Macroinvertebrate response to organic pollution and eutrophication. Freshwater Biology 55:1405-1419. doi: 10.1111/j.1365-2427.2008.02164.x

Gelman A., Hill J. (2007) Data Analysis Using Regression and Multilevel/Hierarchical Models. Cambridge University Press

Gratton C, Zanden MJV (2009) Flux of aquatic insect productivity to land: comparison of lentic and lotic ecosystems. Ecology 90:2689-2699. doi: 10.1890/08-1546.1 
Gray LJ (1989) Emergence Production and Export of Aquatic Insects from a Tallgrass Prairie Stream. The Southwestern Naturalist 34:313-318. doi: 10.2307/36721588

Gray LJ (1993) Response of Insectivorous Birds to Emerging Aquatic Insects in Riparian Habitats of a Tallgrass Prairie Stream. Am Midl Nat 129:288-300. doi: $10.2307 / 2426510$

Greenwood MJ, Booker DJ (2016) Influence of hydrological regime and land cover on traits and potential export capacity of adult aquatic insects from river channels. Oecologia 180:551-566. doi: 10.1007/s00442-015-3462-8

Grueber CE, Nakagawa S, Laws RJ, Jamieson IG (2011) Multimodel inference in ecology and evolution: challenges and solutions: Multimodel inference. J Evol Biol 24:699711. doi: 10.1111/j.1420-9101.2010.02210.x

Gücker B, Brauns M, Solimini AG, et al (2011) Urban stressors alter the trophic basis of secondary production in an agricultural stream. Can J Fish Aquat Sci 68:74-88. doi: 10.1139/F10-126

Hanna DEL, Tomscha SA, Ouellet Dallaire C, Bennett EM (2017) A review of riverine ecosystem service quantification: research gaps and recommendations. J Appl Ecol. doi: $10.1111 / 1365-2664.13045$

Havik G, Catenazzi A, Holmgren M (2014) Seabird Nutrient Subsidies Benefit Non-Nitrogen Fixing Trees and Alter Species Composition in South American Coastal Dry Forests. PLoS ONE 9:e86381. doi: 10.1371/journal.pone.0086381

Hering D, Plachter H (1997) Riparian ground beetles (Coeloptera, Carabidae) preying on aquatic invertebrates: a feeding strategy in alpine floodplains. Oecologia 111:261-270. doi: $10.1007 / \mathrm{s} 004420050234$

Huryn AD, Wallace JB (2000) Life History and Production of Stream Insects. Annu Rev Entomol 45:83-110. doi: 10.1146/annurev.ento.45.1.83

Jackson JK, Fisher SG (1986) Secondary Production, Emergence, and Export of Aquatic Insects of a Sonoran Desert Stream. Ecology 67:629-638. doi: 10.2307/1937686

Johnson BR, Fritz KM, Price R (2013a) Estimating benthic secondary production from aquatic insect emergence in streams affected by mountaintop removal coal mining, West Virginia, USA. Fundam Appl Limnol Arch Für Hydrobiol 182/3:191-204. doi: 10.1127/1863-9135/2013/0403

Johnson RC, Jin H-S, Carreiro MM, Jack JD (2013b) Macroinvertebrate community structure, secondary production and trophic-level dynamics in urban streams affected by non-point-source pollution. Freshw Biol 58:843-857. doi: 10.1111/fwb.12090

Kennedy TL, Turner TF (2011) River channelization reduces nutrient flow and macroinvertebrate diversity at the aquatic terrestrial transition zone. Ecosphere 2:art35. doi: 10.1890/ES11-00047.1

Landry J-S, Parrott L (2016) Could the lateral transfer of nutrients by outbreaking insects lead to consequential landscape-scale effects? Ecosphere 7:e01265. doi: 10.1002/ecs2.1265 
Lemly AD (1982) Modification of benthic insect communities in polluted streams: combined effects of sedimentation and nutrient enrichment. Hydrobiologia 87:229-245. doi: 10.1007/BF00007232

Liess M, Von Der Ohe PC (2005) Analysing effects of pesticides on invertebrate communities in streams. Environ Toxicol Chem 24:954-965. doi: 10.1897/03-652.1

Magbanua FS, Townsend CR, Hageman KJ, et al (2016) Individual and combined effects of fine sediment and glyphosate herbicide on invertebrate drift and insect emergence: a stream mesocosm experiment. Freshw Sci 35:139-151. doi: 10.1086/684363

Martin-Creuzburg D, Kowarik C, Straile D (2017) Cross-ecosystem fluxes: Export of polyunsaturated fatty acids from aquatic to terrestrial ecosystems via emerging insects. Sci Total Environ 577:174-182. doi: 10.1016/j.scitotenv.2016.10.156

Météo France (2017) Données Climatiques de la station de Rennes. source : http://www.meteofrance.com/climat/france/rennes/35281001/normales. Accessed 13 Nov 2017

Motoda, S. 1959. Devices of simple plankton apparatus. Memoirs of the Faculty of Fisheries, Hokkaido University, 1:73-94.

Muehlbauer JD, Collins SF, Doyle MW, Tockner K (2014) How wide is a stream? Spatial extent of the potential "stream signature" in terrestrial food webs using meta-analysis. Ecology 95:44-55. doi: 10.1890/12-1628.1

Nagasaka A, Nakamura F (1999) The influences of land-use changes on hydrology and riparian environment in a northern Japanese landscape. Landsc Ecol 14:543-556. doi: 10.1023/A:1008164123102

Naiman RJ and Décamps H (1997) THE ECOLOGY OF INTERFACES: Riparian Zones. Annu Rev Ecol Syst 28:621-658. doi: 10.1146/annurev.ecolsys.28.1.621

Nakagawa S, Schielzeth H (2013) A general and simple method for obtaining $\mathrm{R}^{2}$ from generalized linear mixed-effects models. Methods in Ecology and Evolution 4:133142. doi: 10.1111/j.2041-210x.2012.00261.x

Nakano S, Murakami M (2001) Reciprocal subsidies: Dynamic interdependence between terrestrial and aquatic food webs. Proc Natl Acad Sci U S A 98:166-170

Paetzold A, Schubert CJ, Tockner K (2005) Aquatic Terrestrial Linkages Along a BraidedRiver: Riparian Arthropods Feeding on Aquatic Insects. Ecosystems 8:748-759. doi: 10.1007/s0021-005-0004-y

Pella, H., Lejot, J., Lamouroux, N. 2012. Le réseau hydrographique théorique (RHT) français et ses attributs environnementaux, Géomorphologie : relief, processus, environnement

Piscart C, Genoel R, Doledec S, et al (2009) Effects of intense agricultural practices on heterotrophic processes in streams. Environ Pollut 157:1011-1018. doi: 10.1016/j.envpol.2008.10.010 
Piscart C, Navel S, Maazouzi C, et al (2011) Leaf litter recycling in benthic and hyporheic layers in agricultural streams with different types of land use. Sci Total Environ 409:4373-4380. doi: 10.1016/j.scitotenv.2011.06.060

Poepperl R (2000) Benthic secondary production and biomass of insects emerging from a northern German temperate stream. Freshw Biol 44:199-211. doi: 10.1046/j.13652427.2000.00558.x

Polis GA, Anderson WB, Holt RD (1997) Toward an integration of landscape and food web ecology: the dynamics of spatially subsidized food webs. Annual review of ecology and systematics $289-316$

Popova ON, Haritonov AY, Sushchik NN, et al (2017) Export of aquatic productivity, including highly unsaturated fatty acids, to terrestrial ecosystems via Odonata. Sci Total Environ 581-582:40-48. doi: 10.1016/j.scitotenv.2017.01.017

QGIS Development Team, 2009. QGIS Geographic Information System. Open Source Geospatial Foundation. URL http://qgis.osgeo.org

Quinn JM, Hickey CW (1990) Characterisation and classification of benthic invertebrate communities in 88 New Zealand rivers in relation to environmental factors. New Zealand Journal of Marine and Freshwater Research 24:387-409. doi: $10.1080 / 00288330.1990 .9516432$

Rabení CF, Doisy KE, Zweig LD (2005) Stream invertebrate community functional responses to deposited sediment. Aquat Sci 67:395-402. doi: 10.1007/s00027-005-0793-2

Raitif J, Plantegenest M, Piscart C, Roussel J-M (in revision) From stream to land: ecosystem services provided by stream insects to agriculture. Agric Ecosyst Environ

Rand TA, Tylianakis JM, Tscharntke T (2006) Spillover edge effects: the dispersal of agriculturally subsidized insect natural enemies into adjacent natural habitats. Ecol Lett 9:603-614. doi: 10.1111/j.1461-0248.2006.00911.x

R Core Team (2013) R: A language and environment for statistical computing. R Foundation for Statistical Computing, Vienna, Austria

Reynolds SK, Benke AC (2012) Chironomid production along a hyporheic gradient in contrasting stream types. Freshw Sci 31:167-181. doi: 10.1899/11-017.1

Richardson JS, Zhang Y, Marczak LB (2010) Resource subsidies across the land-freshwater interface and responses in recipient communities. River Res Appl 26:55-66. doi: $10.1002 /$ rra. 1283

Sallenave RM, Day KE (1991) Secondary production of benthic stream invertebrates in agricultural watersheds with different land management practices. Chemosphere 23:57-76. doi: 10.1016/0045-6535(91)90116-U

Shieh S-H, Ward JV, Kondratieff BC (2003) Longitudinal changes in macroinvertebrate production in a stream affected by urban and agricultural activities. Arch Für Hydrobiol 157:483-503. doi: 10.1127/0003-9136/2003/0157-0483 
Sponseller RA, Benfield EF, Valett HM (2001) Relationships between land use, spatial scale and stream macroinvertebrate communities. Freshw Biol 46:1409-1424. doi: 10.1046/j.1365-2427.2001.00758.x

Statzner B, Resh VH (1993) Multiple-site and-year analyses of stream insect emergence: a test of ecological theory. Oecologia 96:65-79. doi: 10.1007/BF00318032

Stenroth K, Polvi LE, Fältström E, Jonsson M (2015) Land-use effects on terrestrial consumers through changed size structure of aquatic insects. Freshw Biol 60:136-149. doi: $10.1111 /$ fwb. 12476

Tachet H, Richoux P, Bournaud M, Usseglio-Polatera P (2010) Invertébrés d'eau douce systématique, biologie, écologie. CNRS éd., Paris

Wagenhoff A, Townsend CR, Phillips N, Matthaei CD (2011) Subsidy-stress and multiplestressor effects along gradients of deposited fine sediment and dissolved nutrients in a regional set of streams and rivers: Sediment and nutrients in streams. Freshw Biol 56:1916-1936. doi: 10.1111/j.1365-2427.2011.02619.x

Werneke U, Zwick P (1992) Mortality of the terrestrial adult and aquatic nymphal life stages of Baetis vernus and Baetis rhodani in the Breitenbach, Germany (Insecta: Ephemeroptera). Freshwater Biology 28:249-255. doi: 10.1111/j.13652427.1992.tb00581.x

Whittingham MJ, Stephens PA, Bradbury RB, Freckleton RP (2006) Why do we still use stepwise modelling in ecology and behaviour? Journal of Animal Ecology 75:11821189. doi: 10.1111/j.1365-2656.2006.01141.x

Yuen EYL, Dudgeon D (2016) The magnitude and seasonality of aquatic insect subsidies to tropical stream riparia in Hong Kong. Aquat Sci 78:655-667. doi: 10.1007/s00027015-0455-y

Zuur A, Ieno EN, Walker N, et al (2009) Mixed Effects Models and Extensions in Ecology with R. Springer-Verlag, New York 
Table 1. Comparison of temporal and spatial fitted mix-models for each taxon. Summarizing statistics are: Akaike Information Criterion score corrected for small sample size $\left(\mathrm{AIC}_{\mathrm{c}}\right)$, the variance explained by fixed parameters (marginal $\mathrm{R}^{2}$ ) and both fixed and random parameters (conditional $\mathrm{R}^{2}$ ) of the model. Null models are intercept-only models, which have no fixed parameter and the same random structure as fitted models. They are used as bases of comparison against fitted models for $\mathrm{AICc}$ and $\mathrm{R}^{2}$. For a given taxon and scale (i.e. temporal or spatial), lower AICc indicates a better fit of the model to the data, higher marginal/conditional $\mathrm{R}^{2}$ indicate greater goodness-of-fit (the amount of variance explained).

\begin{tabular}{|c|c|c|c|c|c|c|}
\hline & & Tempora & & Spatial $\mathrm{m}$ & & \\
\hline Taxon & Statistic & Null & Sampling campaign & Null & Watershed & Site \\
\hline Chironomidae & $\mathrm{AIC}_{\mathrm{c}}$ & 305.1 & 298.6 & 301.8 & 294.9 & 293.5 \\
\hline & Marginal/conditional $\mathrm{R}^{2}$ & $0.0 / 22.0$ & $10.9 / 34.9$ & $0.0 / 32.7$ & $21.4 / 32.5$ & $15.9 / 41.9$ \\
\hline Trichoptera & $\mathrm{AIC}_{\mathrm{c}}$ & 323.6 & 285.4 & 294.3 & 292.2 & 272.0 \\
\hline & Marginal/conditional $\mathrm{R}^{2}$ & $0.0 / 13.3$ & $34.1 / 52.4$ & $0.0 / 52.5$ & $11.6 / 50.5$ & $23.9 / 57.2$ \\
\hline Ephemeroptera & $\mathrm{AIC}_{\mathrm{c}}$ & 225.3 & 196.1 & 204.2 & 195.7 & 201.7 \\
\hline & Marginal/conditional $\mathrm{R}^{2}$ & $0.0 / 11.4$ & $33.9 / 52.1$ & $0.0 / 51.8$ & $18.8 / 50.9$ & $11.9 / 43.5$ \\
\hline
\end{tabular}


Table 2. Mean annual dry mass (with range of values in brackets when available) of emerging aquatic insect or secondary production. Values in italics correspond to estimates based on the Poepperl (2000) Emergence:Production ratio. EPT = Ephemeroptera, Plecoptera and Trichoptera.

\begin{tabular}{|c|c|c|c|c|c|c|}
\hline References & Location & $\begin{array}{l}\text { Stream order } \\
\text { or width }\end{array}$ & Landscape & $\begin{array}{l}\text { Annual } \\
\text { emergence } \\
\mathrm{g} \mathrm{m}^{-2}\end{array}$ & $\begin{array}{l}\text { Annual secondary } \\
\text { production } \\
\mathrm{g} \mathrm{m}^{-2}\end{array}$ & Taxa \\
\hline \multirow[t]{3}{*}{ Jackson \& Fisher 1986} & Arizona, USA & $3-4 \mathrm{~m}$ & Desert & 13.8 & 58.3 & Chironomidae \\
\hline & & & & 4.4 & 55.5 & Ephemeroptera \\
\hline & & & & 2.9 & 3.6 & Trichoptera \\
\hline Berg \& Hellenthal 1991 & Indiana, USA & third order & Agriculture/Forest & 5.4 & 29.7 & Chironomidae \\
\hline Sallenave et Day, 1991 & Ontario, Canada & $2-4 \mathrm{~m}$ & Agriculture/Forest & $2.9[1.1-4.7]$ & $15.6[5.8-25.4]$ & Trichoptera \\
\hline \multirow[t]{3}{*}{ Poepperl 2000} & Schleswig-Holstein, Germany & $6 \mathrm{~m}$ & Agriculture & $1.1[0.6-1.3]$ & $5.3[3-6.1]$ & Diptera \\
\hline & & & & $0.1[0.01-0.1]$ & $0.6[<0.1-0.9]$ & Ephemeroptera \\
\hline & & & & $0.5[0.3-0.6]$ & $1.9[1-2.1]$ & Trichoptera \\
\hline \multirow[t]{3}{*}{ Shieh et al. 2003} & Colorado, USA & fifth order & Agriculture & $4.2[3.3-5]$ & $23.2[17.9-27.2]$ & Chironomidae \\
\hline & & & & $0.4[0-0.7]$ & $2.4[0.02-3.7]$ & Ephemeroptera \\
\hline & & & & $1.7[0.4-2.2]$ & $9.5[2.3-12]$ & Trichoptera \\
\hline Gücker et al. 2011 & Berlin, Germany & $3-4 \mathrm{~m}$ & Agriculture & - & $3.9[0.4-70.9]$ & $\begin{array}{l}\text { EPT + Chironomidae } \\
+ \text { other taxa }\end{array}$ \\
\hline Reynolds \& Benke 2012 & Alabama, USA & second order & Forest & $5.3[1.4-12.5]$ & $29.2[7.8-68.3]$ & Chironomidae \\
\hline \multirow[t]{2}{*}{ Johnson et al. 2013} & Kentucky, USA & $6 \mathrm{~m}$ & Agriculture/Forest & - & 21.8 & $\begin{array}{l}\text { EPT + Chironomidae } \\
+ \text { other taxa }\end{array}$ \\
\hline & & $6 \mathrm{~m}$ & Agriculture/Forest & 1.4 & 7.5 & EPT \\
\hline Yuen \& Dudgeon 2016 & Hong Kong, China & third or fourth order & Forest & $0.9[0.7-1.2]$ & $4.9[3.8-6.6]$ & $\begin{array}{l}\text { EPT }+ \text { Chironomidae } \\
+ \text { other taxa }\end{array}$ \\
\hline \multirow[t]{4}{*}{ This study } & Brittany, France & third order & Agriculture & $3.8[1.4-7.4]$ & $21[7.9-40.2]$ & EPT + Chironomidae \\
\hline & & & & $1.1[0.2-2.2]$ & $6.1[1.3-11.8]$ & Chironomidae \\
\hline & & & & $0.7[0.1-1.6]$ & $3.7[0.4-7.6]$ & Ephemeroptera \\
\hline & & & & $2.1[0.7-4.9]$ & $11.2[2.9-24.8]$ & Trichoptera \\
\hline
\end{tabular}



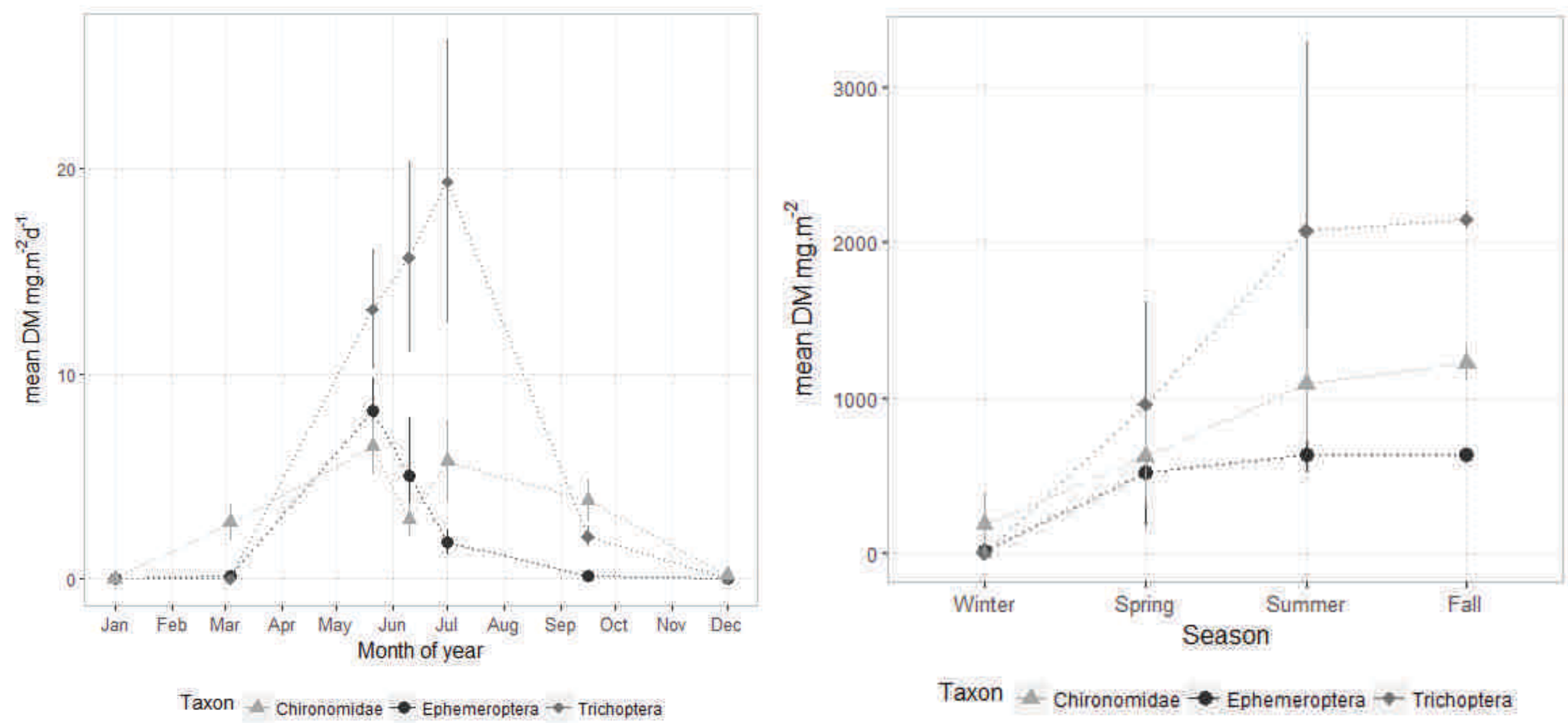

Figure 1. Emergence of aquatic insects dry mass (DM) all sites combined. Left panel shows mean ( \pm 1 standard deviation SD) daily values for each sampling date and taxonomic group. Right panel shows the mean ( $\pm 1 \mathrm{SD})$ cumulative emergence by season (see text for details). 

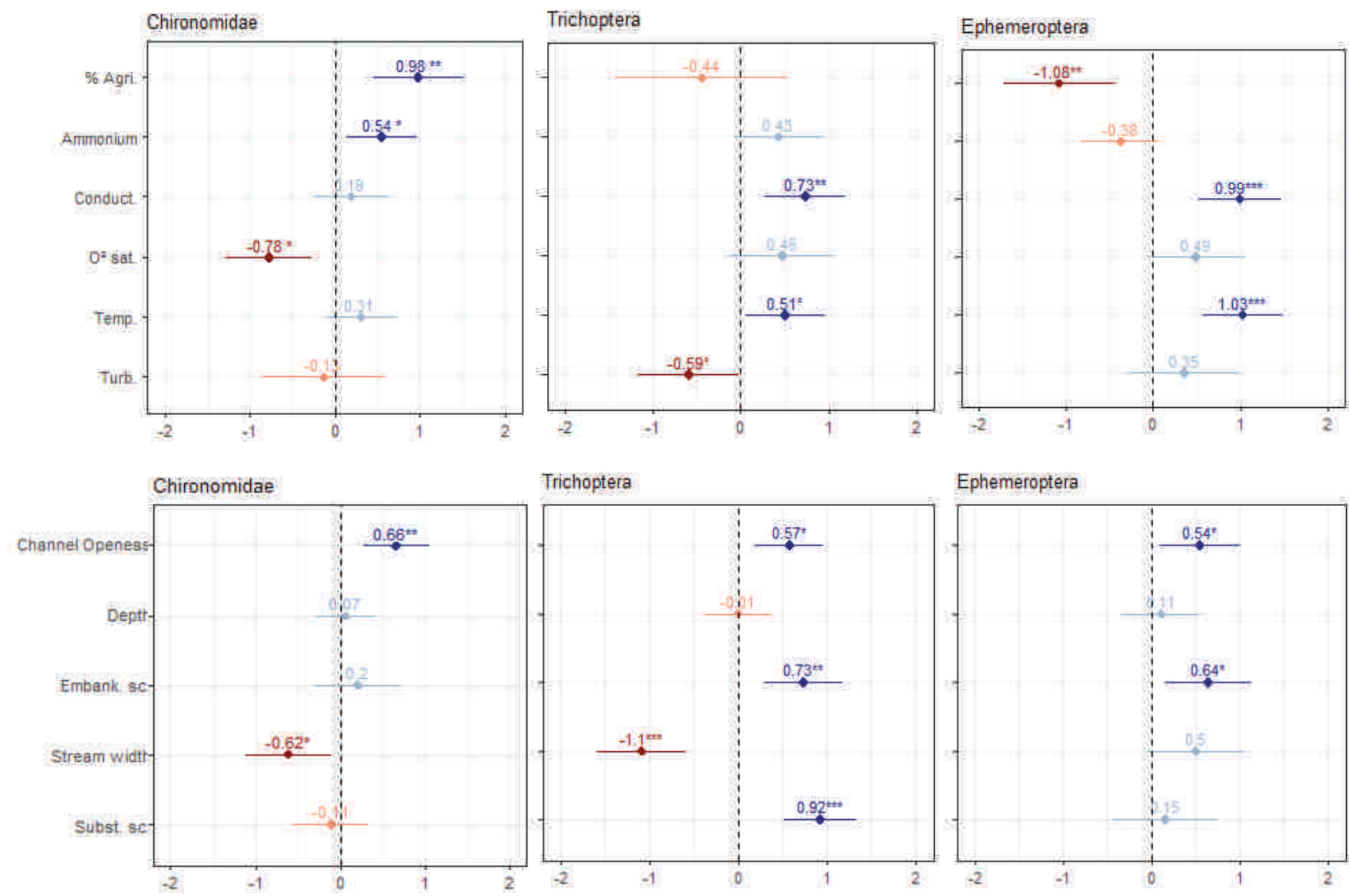

\section{Trichoptera}
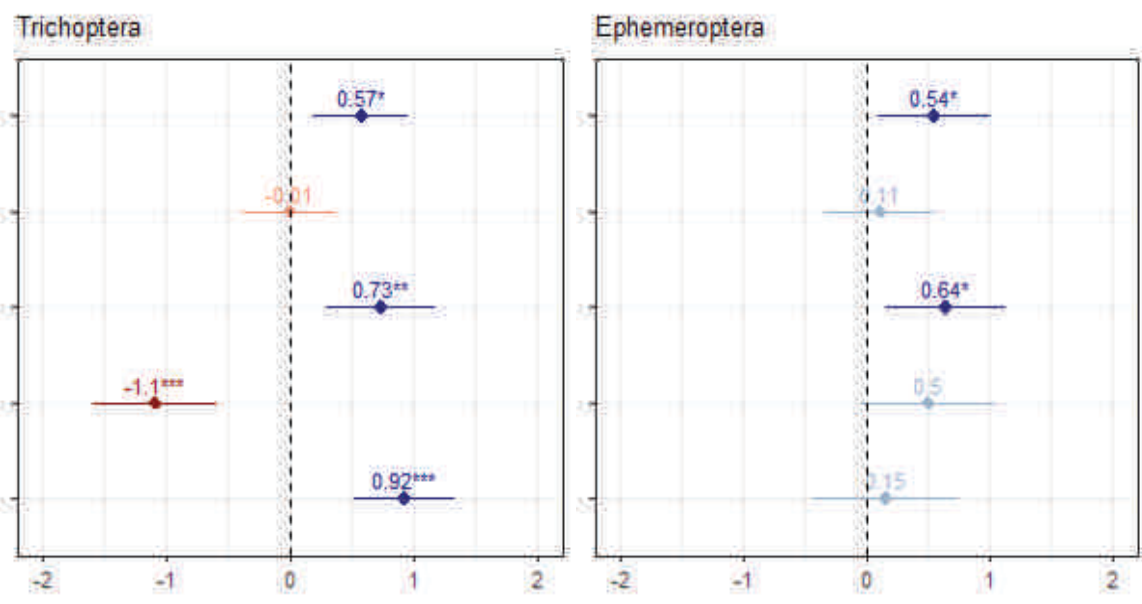

Figure 2. Standardized effect of environmental variables (mean effect size $\pm 90 \%$ confidence interval) at watershed and site scales on emerging

biomass of Chironomidae (left), Trichoptera (middle) and Ephemeroptera (right). Upper panel: Watershed-scale variables; \% Agri = Percentage

of watershed area covered by agriculture (cropland and pasture), Ammonium $=$ Ammonium $\left(\mathrm{NH}_{4}+\right)$ concentration in water, Conductivity $=$ 
Water conductivity, $\mathrm{O}^{2}$ Sat. $=$ Oxygen saturation, Temp. $=$ Water temperature, Turb. $=$ Water turbidity. Lower panel: Site-scale variables;

Channel Openness $=$ Proportion of non-canopy cover over the stream channel, Depth $=$ Water depth, Embank. Sc. $=$ Stream width divided by bank height, Stream width = channel width, Subst. sc. = Substratum score, based on modified Wenworth classification (Cummins, 1962).

Colors indicate degree of positive or negative effect. ${ }^{\circ}=\mathrm{p}<0.10, *=\mathrm{p}<0.05, * *=\mathrm{p}<0.01, * * *=\mathrm{p}<0.001$ 
Table 1. Comparison of temporal and spatial fitted mix-models for each taxon. Summarizing statistics are: Akaike Information Criterion score corrected for small sample size $\left(\mathrm{AIC}_{\mathrm{c}}\right)$, the variance explained by fixed parameters (marginal $\mathrm{R}^{2}$ ) and both fixed and random parameters (conditional $\mathrm{R}^{2}$ ) of the model. Null models are intercept-only models, which have no fixed parameter and the same random structure as fitted models. They are used as bases of comparison against fitted models for $\mathrm{AICc}$ and $\mathrm{R}^{2}$. For a given taxon and scale (i.e. temporal or spatial), lower AICc indicates a better fit of the model to the data, higher marginal/conditional $\mathrm{R}^{2}$ indicate greater goodness-of-fit (the amount of variance explained).

\begin{tabular}{|c|c|c|c|c|c|c|}
\hline & & Tempora & & Spatial $\mathrm{m}$ & & \\
\hline Taxon & Statistic & Null & Sampling campaign & Null & Watershed & Site \\
\hline \multirow[t]{2}{*}{ Chironomidae } & $\mathrm{AIC}_{\mathrm{c}}$ & 305.1 & 298.6 & 301.8 & 294.9 & 293.5 \\
\hline & Marginal/conditional $\mathrm{R}^{2}$ & $0.0 / 22.0$ & $10.9 / 34.9$ & $0.0 / 32.7$ & $21.4 / 32.5$ & $15.9 / 41.9$ \\
\hline \multirow[t]{2}{*}{ Trichoptera } & $\mathrm{AIC}_{\mathrm{c}}$ & 323.6 & 285.4 & 294.3 & 292.2 & 272.0 \\
\hline & Marginal/conditional $\mathrm{R}^{2}$ & $0.0 / 13.3$ & $34.1 / 52.4$ & $0.0 / 52.5$ & $11.6 / 50.5$ & $23.9 / 57.2$ \\
\hline \multirow[t]{2}{*}{ Ephemeroptera } & $\mathrm{AIC}_{\mathrm{c}}$ & 225.3 & 196.1 & 204.2 & 195.7 & 201.7 \\
\hline & Marginal/conditional $\mathrm{R}^{2}$ & $0.0 / 11.4$ & $33.9 / 52.1$ & $0.0 / 51.8$ & $18.8 / 50.9$ & $11.9 / 43.5$ \\
\hline
\end{tabular}


Table 2. Mean annual dry mass (with range of values in brackets when available) of emerging aquatic insect or secondary production. Values in italics correspond to estimates based on the Poepperl (2000) Emergence:Production ratio. EPT = Ephemeroptera, Plecoptera and Trichoptera.

\begin{tabular}{|c|c|c|c|c|c|c|}
\hline References & Location & $\begin{array}{l}\text { Stream order } \\
\text { or width }\end{array}$ & Landscape & $\begin{array}{l}\text { Annual } \\
\text { emergence } \\
\mathrm{g} \mathrm{m}^{-2}\end{array}$ & $\begin{array}{l}\text { Annual secondary } \\
\text { production } \\
\mathrm{g} \mathrm{m}^{-2}\end{array}$ & Taxa \\
\hline \multirow[t]{3}{*}{ Jackson \& Fisher 1986} & Arizona, USA & $3-4 \mathrm{~m}$ & Desert & 13.8 & 58.3 & Chironomidae \\
\hline & & & & 4.4 & 55.5 & Ephemeroptera \\
\hline & & & & 2.9 & 3.6 & Trichoptera \\
\hline Berg \& Hellenthal 1991 & Indiana, USA & third order & Agriculture/Forest & 5.4 & 29.7 & Chironomidae \\
\hline Sallenave et Day, 1991 & Ontario, Canada & $2-4 \mathrm{~m}$ & Agriculture/Forest & $2.9[1.1-4.7]$ & $15.6[5.8-25.4]$ & Trichoptera \\
\hline \multirow[t]{3}{*}{ Poepperl 2000} & Schleswig-Holstein, Germany & $6 \mathrm{~m}$ & Agriculture & $1.1[0.6-1.3]$ & $5.3[3-6.1]$ & Diptera \\
\hline & & & & $0.1[0.01-0.1]$ & $0.6[<0.1-0.9]$ & Ephemeroptera \\
\hline & & & & $0.5[0.3-0.6]$ & $1.9[1-2.1]$ & Trichoptera \\
\hline \multirow[t]{3}{*}{ Shieh et al. 2003} & Colorado, USA & fifth order & Agriculture & $4.2[3.3-5]$ & $23.2[17.9-27.2]$ & Chironomidae \\
\hline & & & & $0.4[0-0.7]$ & $2.4[0.02-3.7]$ & Ephemeroptera \\
\hline & & & & $1.7[0.4-2.2]$ & $9.5[2.3-12]$ & Trichoptera \\
\hline Gücker et al. 2011 & Berlin, Germany & $3-4 \mathrm{~m}$ & Agriculture & - & $3.9[0.4-70.9]$ & $\begin{array}{l}\text { EPT + Chironomidae } \\
+ \text { other taxa }\end{array}$ \\
\hline Reynolds \& Benke 2012 & Alabama, USA & second order & Forest & $5.3[1.4-12.5]$ & $29.2[7.8-68.3]$ & Chironomidae \\
\hline \multirow[t]{2}{*}{ Johnson et al. 2013} & Kentucky, USA & $6 \mathrm{~m}$ & Agriculture/Forest & - & 21.8 & $\begin{array}{l}\text { EPT + Chironomidae } \\
+ \text { other taxa }\end{array}$ \\
\hline & & $6 \mathrm{~m}$ & Agriculture/Forest & 1.4 & 7.5 & EPT \\
\hline Yuen \& Dudgeon 2016 & Hong Kong, China & third or fourth order & Forest & $0.9[0.7-1.2]$ & $4.9[3.8-6.6]$ & $\begin{array}{l}\text { EPT }+ \text { Chironomidae } \\
+ \text { other taxa }\end{array}$ \\
\hline \multirow[t]{4}{*}{ This study } & Brittany, France & third order & Agriculture & $3.8[1.4-7.4]$ & $21[7.9-40.2]$ & EPT + Chironomidae \\
\hline & & & & $1.1[0.2-2.2]$ & $6.1[1.3-11.8]$ & Chironomidae \\
\hline & & & & $0.7[0.1-1.6]$ & $3.7[0.4-7.6]$ & Ephemeroptera \\
\hline & & & & $2.1[0.7-4.9]$ & $11.2[2.9-24.8]$ & Trichoptera \\
\hline
\end{tabular}



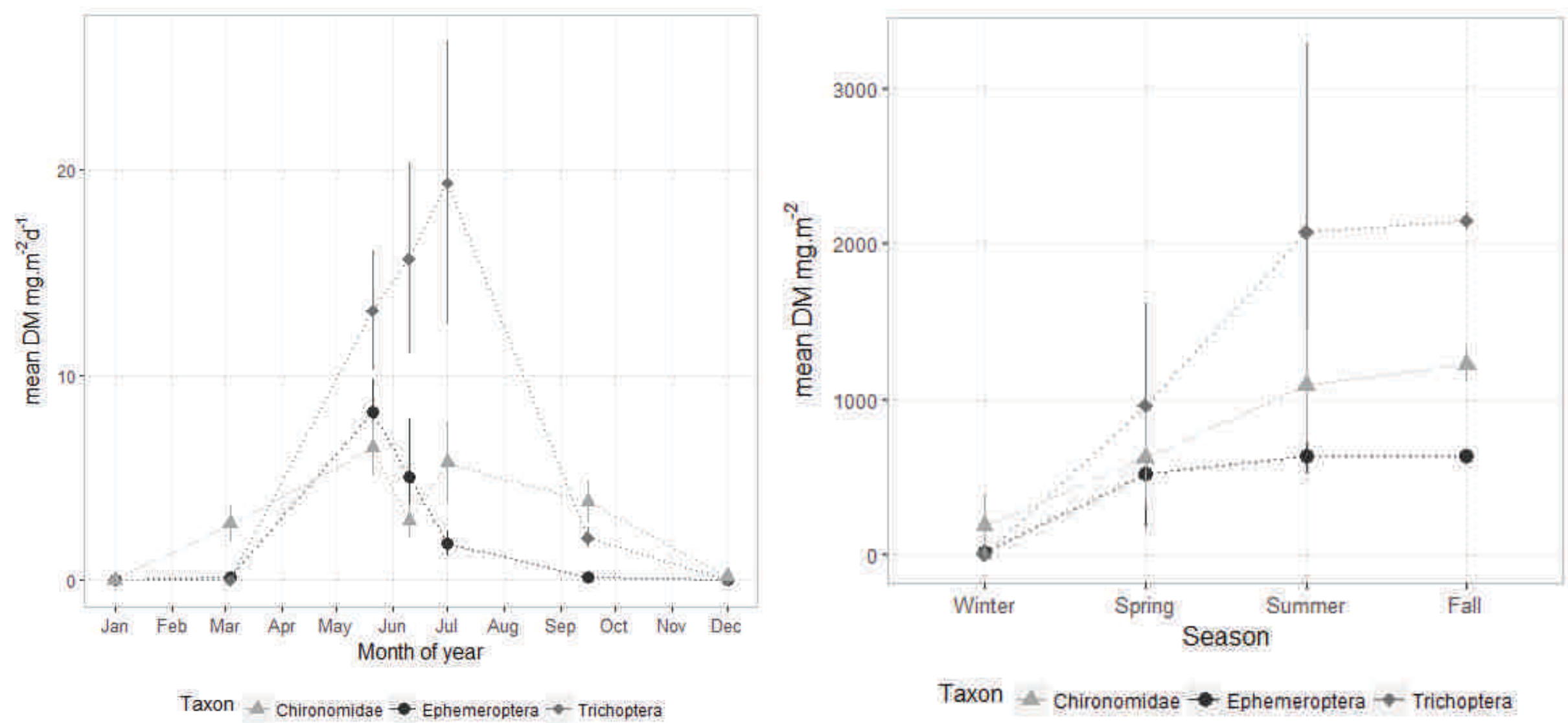

Figure 1. Emergence of aquatic insects dry mass (DM) all sites combined. Left panel shows mean ( \pm 1 standard deviation SD) daily values for each sampling date and taxonomic group. Right panel shows the mean ( $\pm 1 \mathrm{SD})$ cumulative emergence by season (see text for details). 

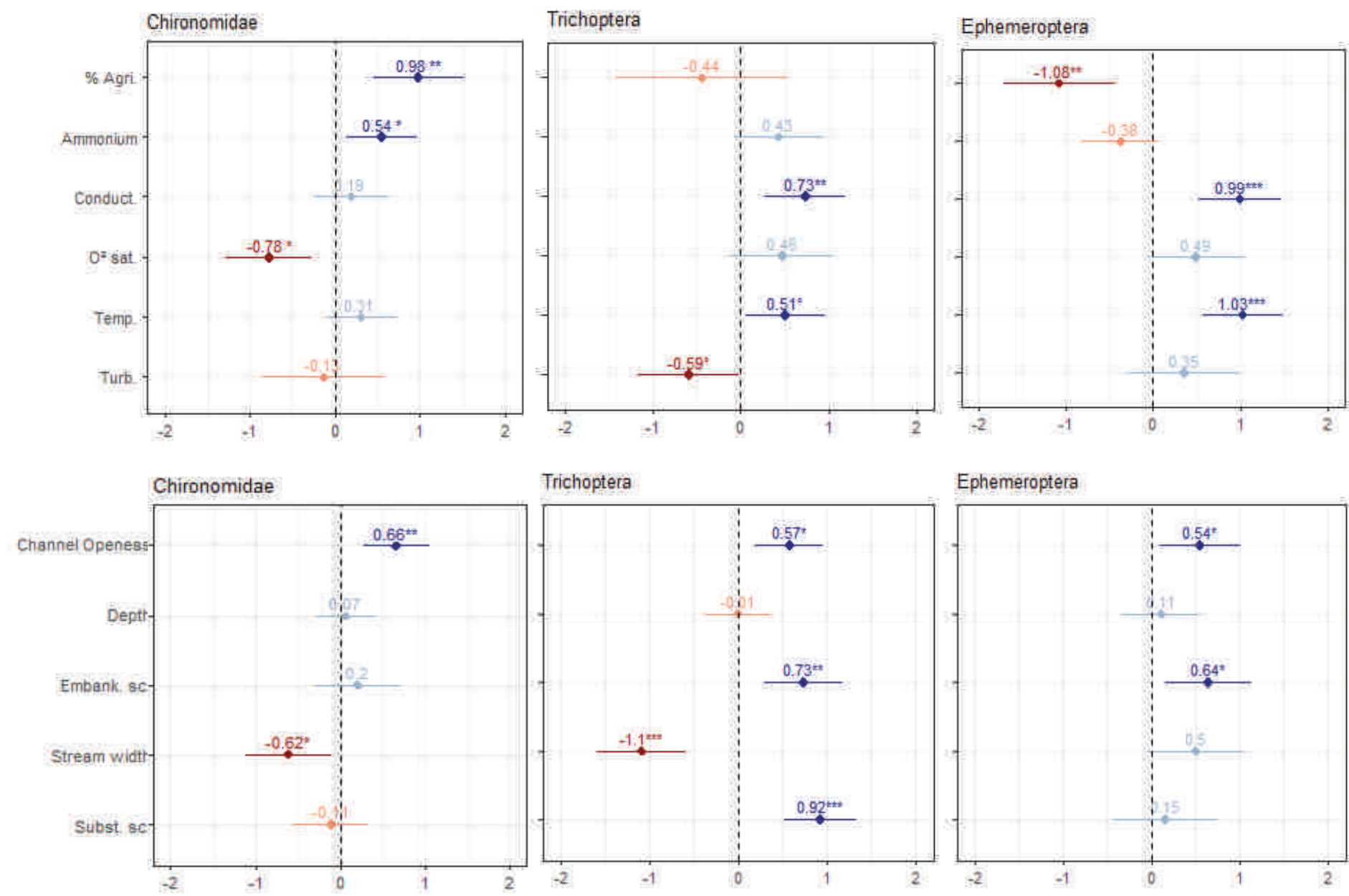

\section{Trichoptera}
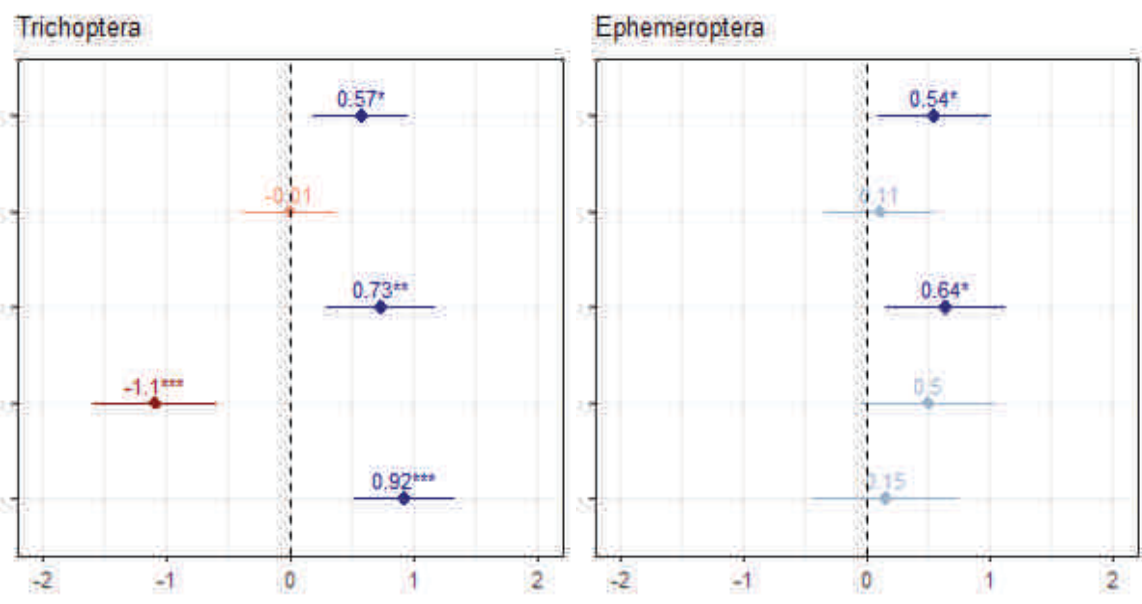

Figure 2. Standardized effect of environmental variables (mean effect size $\pm 90 \%$ confidence interval) at watershed and site scales on emerging biomass of Chironomidae (left), Trichoptera (middle) and Ephemeroptera (right). Upper panel: Watershed-scale variables; \% Agri = Percentage of watershed area covered by agriculture (cropland and pasture), Ammonium $=$ Ammonium $\left(\mathrm{NH}_{4}+\right)$ concentration in water, Conductivity $=$ 
Water conductivity, $\mathrm{O}^{2}$ Sat. $=$ Oxygen saturation, Temp. $=$ Water temperature, Turb. $=$ Water turbidity. Lower panel: Site-scale variables;

Channel Openness $=$ Proportion of non-canopy cover over the stream channel, Depth $=$ Water depth, Embank. Sc. $=$ Stream width divided by bank height, Stream width $=$ channel width, Subst. sc. = Substratum score, based on modified Wenworth classification (Cummins, 1962).

Colors indicate degree of positive or negative effect. ${ }^{\circ}=\mathrm{p}<0.10, *=\mathrm{p}<0.05, * *=\mathrm{p}<0.01, * * *=\mathrm{p}<0.001$ 
